DOI: [10.9774/GLEAF.2350.2015.ju.00002]

Editorial

\title{
Sustainable Mobility in China from a Global Perspective
}

Volume 2 Issue 1 June 2015

Michael Zhang

Nottingham Trent University, UK

READING THE NEWLY PUBLISHED Synthesis Report (SYR) on Climate Change 2014 by the Intergovernmental Panel on Climate Change (IPCC, 20I5), it becomes clear that there is increasing scientific evidence of anthropogenic impact, i.e. influence of human activities, on global climate change. Of particular concern are the continued increases of $\mathrm{CO}_{2}$ emissions and $\mathrm{CO}_{2}$ concentration in the atmosphere. The SYR notes that ' $\mathrm{CO}_{2}$ concentrations are increasing at the fastest observed decadal rate of change (2.0 \pm O.I ppm/yr) for 2002-20II' (ibid.: 44). This reflects our summary of the changes of $\mathrm{CO}_{2}$ concentrations using previous IPCC and IEA data (Zhang and Yazdani, 20I4). The magnitude of annual $\mathrm{CO}_{2}$ emissions was 30.3 gigatonnes in 2010 and the level of $\mathrm{CO}_{2}$ concentration reached 400 parts per million (ppm) in 20I3 (IEA, 20I2; IPCC, 20I3). Over the period of 23 years between 1990 and 2013 the level of $\mathrm{CO}_{2}$ concentration rose from 353 $\mathrm{ppm}$ to $400 \mathrm{ppm}$ giving it an average annual increase of $2.04 \mathrm{ppm} / \mathrm{yr}$. If this trend remains unchanged $\mathrm{CO}_{2}$ concentration will by circa 2037 have reached the level of $450 \mathrm{ppm}$ which is the baseline of $\mathrm{CO}_{2}$ concentration stabilisation used by many researchers for modelling global climate change. The IPCC experts estimate with high confidence that about $50 \%$ of the cumulative $\mathrm{CO}_{2}$ emissions generated by human activities during the industrial period between I750 and 20II occurred in the last 40 years (IPCC, 2015: 45). Indeed, in the last 30 years or so the world has witnessed marked changes in the contributions of $\mathrm{CO}_{2}$ emissions by some leading nations. As the leading industrialised country the US had been the largest $\mathrm{CO}_{2}$ emission contributor until 2007, when it was overtaken by China. In 1980 the US contributed $25.8 \%$ of the 18.0 gigatonnes of world $\mathrm{CO}_{2}$ emissions. In comparison, in the same year China's contribution of $\mathrm{CO}_{2}$ emissions accounted for only $7.9 \%$ as shown in Table I (IEA, 20I2). 
Table $1 \mathrm{CO}_{2}$ emissions from selected countries/regions 1980-2010 (million tonnes)

Source: IEA, 2012

\begin{tabular}{lllcccccc}
\hline & 1980 & & 1990 & & 2000 & & 2010 & \\
\hline & Total & $\%$ & Total & $\%$ & Total & $\%$ & Total & $\%$ \\
\hline China & 1,420 & 7.9 & 2,244 & 10.7 & 3,077 & 13.1 & 7,259 & 24.0 \\
\hline USA & 4,662 & 25.8 & 4,869 & 23.2 & 5,698 & 24.2 & 5,369 & 17.7 \\
\hline EU27 & $\mathrm{n} / \mathrm{a}$ & $\mathrm{n} / \mathrm{a}$ & 4,050 & 19.3 & 3,831 & 16.3 & 3,660 & 12.1 \\
\hline World & 18,042 & 100 & 20,974 & 100 & 23,509 & 100 & 30,276 & 100 \\
\hline
\end{tabular}

In I990 the total world $\mathrm{CO}_{2}$ emissions rose to 2I.o gigatonnes, of which the US contributed $23.2 \%$ and China I0.7\%. EUI5, a collective body of I5 European countries before 2004 , contributed I9.3\% in I990. The following two decades saw three clear trends emerging: (I) continued reduction of $\mathrm{CO}_{2}$ emissions in the EUI5 then and now EU27; (2) slightly fluctuating with overall decrease of $\mathrm{CO}_{2}$ emissions in the US; and (3) significant increase of $\mathrm{CO}_{2}$ emissions in China. As a result, reduction of $\mathrm{CO}_{2}$ emissions in China has become a priority in the national policy agenda, as Zhao, Hao and Zhang argue in the Guest Editorial of this Special Issue.

The global transport sector in general is the second largest contributor to total $\mathrm{CO}_{2}$ emissions. In EU27 countries $\mathrm{CO}_{2}$ emissions from the transport sector accounted for $24.3 \%$ in 20I2, below that from the energy sector at 29.2\% (European Commission, 20I2). Particularly important is the annual change of $\mathrm{CO}_{2}$ emissions over the I990 level. Categorically all sectors (including energy, industry, residential and commercial) but transport have seen to various degrees reduction in $\mathrm{CO}_{2}$ emissions from I990 to 2012 (ibid.). This pattern was formed in the context of stabilisation of vehicle ownership of 567 vehicles per I,000 people in EU27 in 2010 (Ward's, 20I3). In stark contrast, vehicle ownership in China was merely 58 vehicles per $\mathrm{I}, 000$ people in $20 \mathrm{IO}$. As a result, $\mathrm{CO}_{2}$ emissions from China's transport sector accounted for only $7.5 \%$ of the total 7,259 million tonnes in 2010, far below the world average $22.3 \%$ and the significantly higher rate of $30.2 \%$ registered for the US as shown in Table 2.

Table $2 \mathrm{CO}_{2}$ emissions from the transport sector in selected countries/regions 2010 (million tonnes)

Source: IEA, 2012

\begin{tabular}{lcccccc}
\hline & $\begin{array}{l}\text { Total } \\
(\mathrm{A})\end{array}$ & $\%$ & $\begin{array}{l}\text { Transport } \\
(\mathrm{B})\end{array}$ & $\begin{array}{l}\% \\
(\mathrm{~B} / \mathrm{A})\end{array}$ & $\begin{array}{l}\text { Road transport } \\
(\mathrm{C})\end{array}$ & $\begin{array}{l}\% \\
(\mathrm{C} / \mathrm{B})\end{array}$ \\
\hline China & 7,259 & 24.0 & 546 & 7.5 & 401 & 73.4 \\
\hline US & 5,369 & 17.7 & 1,621 & 30.2 & 1,401 & 86.4 \\
\hline EU27 & 3,660 & 12.1 & 900 & 24.6 & 848 & 94.2 \\
\hline World & 30,276 & 100.0 & 6,756 & 22.3 & 4,972 & 73.6 \\
\hline
\end{tabular}


The development of China's transport systems in general and the road transport system in particular, with its large potential contribution to $\mathrm{CO}_{2}$ emissions in the coming two decades or so, i.e. 2015-2035, demands a special forum of investigation and discussion, and therefore the resultant presentation of this Special Issue (SI) dedicated to the subject. I thank the Guest Editors, Professor Fuquan Zhao and Dr Han Hao from Tsinghua University for their effort and commitment to collecting and editing the papers included in this SI. The contributions to the SI provide a wide range of topics with in-depth analysis of the complex transport systems in China. I hope that the findings from this SI will shed light on our debate and examination of sustainable mobility with special reference to large developing countries.

\section{References}

European Commission (2012). Reducing emissions from transport. European Commission website at http://ec.europa.eu/ clima/policies/transport/index_en.htm accessed on Io April 20I5.

IEA (2OI2). $\mathrm{CO}_{2}$ Emissions from Fuel Combustion, IEA Statistics, International Energy Agency, Paris.

IPCC (20I3). Climate Change 2013: The Physical Science Basis. Contribution of Working Group I to the Fifth Assessment Report of the Intergovernmental Panel on Climate Change, Cambridge University Press, Cambridge, UK.

IPCC (20I5). Climate Change 2014: Synthesis Report. Contribution of Working Groups I, II and III to the Fifth Assessment Report of the Intergovernmental Panel on Climate Change. IPCC, Geneva, Switzerland.
Ward's (2013). World vehicle in use dataset 2006-2010. Wardsauto Data Center, at http://wardsauto.com/data-browseworld accessed on 20 May 2013.

Zhang, M. and Yazdani, B. (20I4). Paradigm Change of Mobility in the Twenty-first Century. Journal of Sustainable Mobility I, 9-I8.

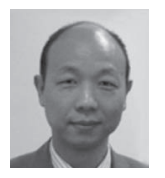

Dr Michael Zhang is Reader in International Strategy at Nottingham Business School, Nottingham Trent University. He teaches core modules of International Business and Strategic Management at both undergraduate and postgraduate levels. His research interest covers the following areas: (I) economic development and market process; (2) technology analysis and entrepreneurship; and (3) corporate sustainability and organisational learning. Before his academic career, Michael worked in the automotive industry and was involved in international technological transfer programmes. He has work experience in China, Japan and the UK and speaks Chinese, English and Japanese. Michael has published in a range of economic and management journals, inter alia: the International Journal of Technology Management, International Small Business Journal, Journal of the Asian Pacific Economy, RQD Management, Technology Analysis Q Strategic Management. He served a term of three years, 20II-I3, as a member of the Editorial Review Board of the Journal of International Business Studies. He was a guest editor for a Special Issue of the International Journal of Entrepreneurship and Innovation in 20I2. In July 2013 he successfully launched, and became the founding Editor-in-Chief of, a new peerreviewed journal: the Journal of Sustainable Mobility with Greenleaf Publishing.

$\triangle$ Nottingham Business School, Nottingham Trent University, Burton Street, Nottingham NG1 4BU, UK

michael.zhang@ntu.ac.uk 